\title{
Variation in Growth Traits of Acrocarpus fraxinifolius Wight and Arn Populations in Southern Karnataka, India
}

\author{
M. N. Ashwath*, B. N. Satish, G. M. Devagiri, R. K. Hegde and T. S. Hareesh
}

Department of Forest Biology and Tree Improvement, College of Forestry, Ponnampet, University of Agricultural and Horticultural sciences, Shivamogga, Karnataka, India

*Corresponding author

\section{Keywords \\ Acrocarpus fraxinifolius, variation, Population, Growth character \\ Article Info \\ Accepted: 18 July 2020 Available Online: 10 August 2020}

\section{A B S T R A C T}

The present investigation was carried out to quantify the variation in growth characters of Acrocarpus fraxinifolius across the selected populations in the coffee growing regions of southern Karnataka. The growth parameters such as total tree height, clear bole height and girth at breast height were recorded and basal area and volume were estimated. Tree height varied significantly and the maximum tree height was recorded in Mudigere and Chikamagaluru $(26.14 \mathrm{~m})$ populations. The difference in GBH was found to be non-significant across the populations, which could be due to selection of trees in particular girth class. The clear bole height of trees varied across the populations from $9.19 \mathrm{~m}$ in Bhagamandala to 18.93 in Totadagadde. Basal area of $A$. fraxinifolius was relatively higher in Shuntikoppa $\left(0.157 \mathrm{~m}^{2}\right)$ and volume was maximum in Balehonnuru population $\left(1.298 \mathrm{~m}^{3}\right)$.

\section{Introduction}

Forests provide myriad tangible and intangible benefits for human wellbeing. In recent decades, wood has become one of the vital forest products and it is an important raw material for forest-based industries such as sawmills, composite and plywood, pulp and paper industries. Acrocarpus fraxinifolius is one of the fast-growing indigenous tree species which is considered to be the promising tree species suitable for making plywood, planks, panel and construction purpose with its other multi-purpose services such as erosion control, fodder, gum, fuel wood, etc. (Nath et al., 2012). Acrocarpus fraxinifolius is a large sized tree belongs to sub-family Caesalpinioideae under family Fabaceae. A. fraxinifolius is the only species under genera Acrocarpus. It is commonly known as Belanji and Havalige (Kannada), Mandane (Bengali), Nelarai (Tamil), Kurangadi (Malayalam), Pink cedar, etc. in different parts of the country. Belanji can grow up to $60 \mathrm{~m}$ tall with the cylindrical bole free from branches up to $3 / 4$ of its total height. Balanji, being timber yielding tree species; it is naturally distributed in high rainfall areas in the evergreen forests of Western Ghats, Sikkim, West Bengal and Assam. It is mostly 
cultivated in Kodagu and South Canara as shade-tree in coffee estates (Troup, 1921; Ghildyal, 1989). Belanji is the most adapted tree species for shade purposes in the coffee plantation with its fast-growing nature and multi-utility purpose among diverse native shade trees viz., Dalbergia, Syzygium, Lagerstroemia, etc. (Nath et al., 2011).

The sapwood of Acrocarpus is white and the heartwood is pinkish, which is commonly used in making veneers and plywood. It is also used as timber in furniture, door, windows, beams, rafters, etc. The wood is used as pulp for making paper (Orwa et al., 2009). The pulp is best suitable for Kraft paper. Though the species is leguminous, it is not capable of fixing the nitrogen; however, it has been recommended for erosion control due to its strong taproot. Leaves are suitable for mulching. Timber is odourless and is suitable for fruit packing cases (Ghildyal, 1989). Trees exude gum like resinous substance when it is felled or cut. Belanji was termed as the tree for the future because of its multi-purpose utility (Mishra et al., 2015) and also recommended as one of the promising species for Agroforestry. The evaluation of variation in growth character is necessary for the delineation of better provenances and the conceptualization of advanced breeding strategies.

For initiation of any breeding program knowing the variation or variability is essential. When the exception is more, there is scope for selection. Variation is influenced by genetic parentage as well as the environment where it is growing. In this context, an effort has been made to assess the variation among the populations from different populations in southern Karnataka.

\section{Materials and Methods}

The present study was carried in three major coffee-growing districts of Karnataka viz.,
Kodagu, Chikamagaluru, and Hassan. Nine populations of Acrocarpus fraxinifolius (Table 1) were selected from the three major coffee growing districts. In order to avoid the variation influenced by the age, 20 trees in the range of $120 \mathrm{~cm}$ to $150 \mathrm{~cm}$ girth at breast height $(\mathrm{GBH})$ were randomly selected from each population in each district. Tree growth parameters such as total tree height, clear bole height and girth at breast height were recorded on each selected trees to study the variation in growth across the selected populations. The basal area and volume were estimated based on the standard formulas mentioned below;

$B A=G^{2} / 4 \pi$

$V=B A \times H \times f f$

Where,

BA is basal area, $\mathrm{G}$ is girth at breast height, $\mathrm{V}$ is volume, $\mathrm{H}$ is total tree height, $\mathrm{ff}$ is form factor (0.33).

\section{Statistical analysis}

The data obtained on growth parameters such as total tree height, clear bole height, girth at breast height $(\mathrm{GBH})$ were subjected to the One-way ANOVA to understand the variation across different populations as described by Panse and Sukhatme (1978) using SPSS 16.0 software.

\section{Hierarchical Grouping}

Hierarchical grouping and dendrogram was done by cluster analysis method of Average Linkage (between groups) with the measure of Squared Euclidean Distance using SPSS 16.0 software as suggested by Pande et al., 2013. 


\section{Results and Discussion}

Phenotypic traits such as total tree height, GBH and clear bole height were considered as the variables and reported to be under adequate control of genotype and environment (Zobel, 1981). The results of the present study exhibited the noticeable dissimilarity among the populations (Table 2).

The total tree height was significantly varied across the populations with a maximum tree height of $32.00 \mathrm{~m}$ and a minimum height of $13.40 \mathrm{~m}$. Among nine populations, Chikamagaluru and Mudigere populations showed maximum mean height of $26.14 \mathrm{~m}$ followed by Balehonnuru $(25.81 \mathrm{~m})$, Sakleshpura (25.68 m), Shuntikoppa (24.85 $\mathrm{m})$, Totadagadde $(23.61 \mathrm{~m})$, Shreemangala $(22.76 \mathrm{~m})$, Bhagamandala $(22.16 \mathrm{~m})$ and Vanaguru (19.99 m) (Fig. 1 a). The clear bole height showed a significant difference (Fig. 1 b) with a maximum mean clear bole height of $18.93 \mathrm{~m}$ in Totadagadde and minimum of $9.18 \mathrm{~m}$ in Bhagamandala population.

Difference in GBH was found to be nonsignificant across the populations which could be due to selection of trees in particular girth class $(1.20 \mathrm{~m}$ to $1.50 \mathrm{~m})$ to avoid the effect of age on other parameters. Across the populations GBH varied between 1.23 to 1.48 $\mathrm{m}$ among the selected trees (Fig. $1 \mathrm{c}$ ). The basal area was also showed statistically nonsignificant variation across the populations. Among the different populations, the highest average basal area of trees was recorded in Shuntikoppa $\left(0.157 \mathrm{~m}^{2}\right)$ and lowest in Vanaguru $\left(0.135 \mathrm{~m}^{2}\right)$ population.

The average basal area varied from 0.109 to $0.225 \mathrm{~m}^{2}$. Estimated volume of the selected trees in different populations is presented in Table 2. Tree volume varied significantly across the populations (Fig. $1 \mathrm{~d}$ ). The highest mean volume was recorded in Balehonnuru $\left(1.298 \mathrm{~m}^{3}\right)$ population whereas, the lowest mean volume was recorded in Vanaguru $\left(0.886 \mathrm{~m}^{3}\right)$ population. The average volume for populations was $1.298 \mathrm{~m}^{3}, 1.296 \mathrm{~m}^{3}$, $1.276 \mathrm{~m}^{3}, 1.267 \mathrm{~m}^{3}, 1.264 \mathrm{~m}^{3}, 1.129 \mathrm{~m}^{3}$, $1.111 \mathrm{~m}^{3}, 1.075 \mathrm{~m}^{3}$ and $0.886 \mathrm{~m}^{3}$ in Balehonnuru, Shuntikoppa, Mudigere, Chikamagaluru, Sakleshpura, Totadagadde, Shreemangala, Bhagamandala and Vanaguru, respectively.

Table.1 Details of geographic locations and weather parameters of selected populations of Acrocarpus fraxinifolius

\begin{tabular}{|c|c|c|c|c|c|c|c|}
\hline \multirow[t]{2}{*}{ Districts } & \multirow[t]{2}{*}{ Population } & \multirow[t]{2}{*}{ Latitude $\left(\mathbf{N}^{\mathbf{0}}\right)$} & \multirow[t]{2}{*}{$\begin{array}{l}\text { Longitude } \\
\quad\left(\mathbf{E}^{o}\right)\end{array}$} & \multirow[t]{2}{*}{$\begin{array}{l}\text { Altitude (m) } \\
\text { (a.m.s. l) }\end{array}$} & \multirow[t]{2}{*}{$\begin{array}{l}\text { Mean annual } \\
\text { rainfall }(\mathrm{mm})\end{array}$} & \multicolumn{2}{|c|}{$\begin{array}{c}\text { Temperature } \\
\left({ }^{\circ} \mathbf{C}\right)\end{array}$} \\
\hline & & & & & & Max. & Min. \\
\hline \multirow[t]{3}{*}{ Kodagu } & Shreemangala & $12^{\circ} 06^{\prime}$ & $76^{\circ} 00^{\prime}$ & 832 & 1986.40 & 28.98 & 17.95 \\
\hline & Shuntikoppa & $12^{\circ} 27^{\prime}$ & $75^{\circ} 50^{\prime}$ & 981 & 1558.90 & 27.95 & 17.79 \\
\hline & Bhagamandala & $12^{\circ} 23^{\prime}$ & $75^{\circ} 31^{\prime}$ & 946 & 4854.50 & 28.66 & 17.87 \\
\hline \multirow{3}{*}{$\begin{array}{l}\text { Chikamagalu } \\
\text { ru }\end{array}$} & Chikamagaluru & $13^{\circ} 16^{\prime}$ & $75^{\circ} 43^{\prime}$ & 1084 & 1305.00 & 28.99 & 16.56 \\
\hline & Balehonnuru & $13^{\circ} 22^{\prime}$ & $75^{\circ} 31^{\prime}$ & 727 & 1584.90 & 30.06 & 17.32 \\
\hline & Mudigere & $13^{\circ} 10^{\prime}$ & $75^{\circ} 39^{\prime}$ & 1030 & 1964.00 & 28.49 & 17.91 \\
\hline \multirow[t]{3}{*}{ Hassan } & Sakleshpura & $12^{\circ} 57^{\prime}$ & $75^{\circ} 48^{\prime}$ & 945 & 2103.23 & 30.70 & 18.67 \\
\hline & Vanaguru & $12^{\circ} 47^{\prime}$ & $75^{\circ} 45^{\prime}$ & 929 & 3559.00 & 29.24 & 17.50 \\
\hline & Totadagadde & $12^{\circ} 56^{\prime}$ & $75^{\circ} 46^{\prime}$ & 932 & 2304.50 & 29.73 & 17.82 \\
\hline
\end{tabular}


Table. 2 Variation in growth parameters across the populations

\begin{tabular}{|c|c|c|c|c|c|}
\hline Populations & $\begin{array}{l}\text { Total tree } \\
\text { height (m) }\end{array}$ & $\begin{array}{c}\text { Clear bole height } \\
\text { (m) }\end{array}$ & $\begin{array}{c}\text { GBH } \\
(\mathbf{m})\end{array}$ & $\begin{array}{c}\text { Basal Area } \\
\left(\mathrm{m}^{2} / \text { tree }\right)\end{array}$ & $\begin{array}{r}\text { Volume } \\
\left(\mathrm{m}^{3} / \text { tree }\right)\end{array}$ \\
\hline Shreemangala & $22.78^{\mathrm{b}}$ & $16.15^{\mathrm{d}}$ & 1.36 & 0.147 & $1.111^{b c}$ \\
\hline Shuntikoppa & $24.85^{\mathrm{cd}}$ & $14.03^{\mathrm{bcd}}$ & 1.41 & 0.157 & $1.296^{c}$ \\
\hline Bhagamandala & $22.16^{b}$ & $9.19^{\mathrm{a}}$ & 1.35 & 0.145 & $1.075^{b}$ \\
\hline Chikamagaluru & $26.14^{\mathrm{d}}$ & $11.53^{\mathrm{ab}}$ & 1.35 & 0.146 & $1.267^{\mathrm{c}}$ \\
\hline Balehonnuru & $25.81^{d}$ & $13.61^{\mathrm{bcd}}$ & 1.38 & 0.152 & $1.298^{c}$ \\
\hline Mudigere & $26.14^{d}$ & $15.02^{d}$ & 1.36 & 0.147 & $1.276^{\mathrm{c}}$ \\
\hline Sakleshpura & $25.68^{d}$ & $14.38^{\mathrm{cd}}$ & 1.36 & 0.149 & $1.264^{c}$ \\
\hline Totadagadde & $23.61^{b c}$ & $18.93^{\mathrm{e}}$ & 1.33 & 0.143 & $1.129^{b c}$ \\
\hline Vanaguru & $19.99^{a}$ & $12.21^{\mathrm{bc}}$ & 1.30 & 0.135 & $0.886^{\mathrm{a}}$ \\
\hline Mean & 24.13 & 13.89 & 1.36 & 0.147 & 1.178 \\
\hline $\operatorname{SEm}( \pm)$ & 0.643 & 0.871 & 0.024 & 0.005 & 0.059 \\
\hline CD@ $9 \%$ & 1.79 & 2.432 & NS & NS & 0.165 \\
\hline
\end{tabular}

Table.3 Population composition of different clusters

\begin{tabular}{|c|c|c|}
\hline Cluster No. & No. of populations & Populations \\
\hline I & 5 & Mudigere, Sakleshpura, Shuntikoppa, Balehonnuru, Chikamagaluru \\
\hline II & 2 & Bhagamandala, Vanaguru \\
\hline III & 2 & Shreemangala, Totadagadde \\
\hline
\end{tabular}

Fig.1 Variation in (a) total tree height, (b) clear bole height, (c) girth at breast height, (d) volume across the selected Acrocarpus fraxinifolius population
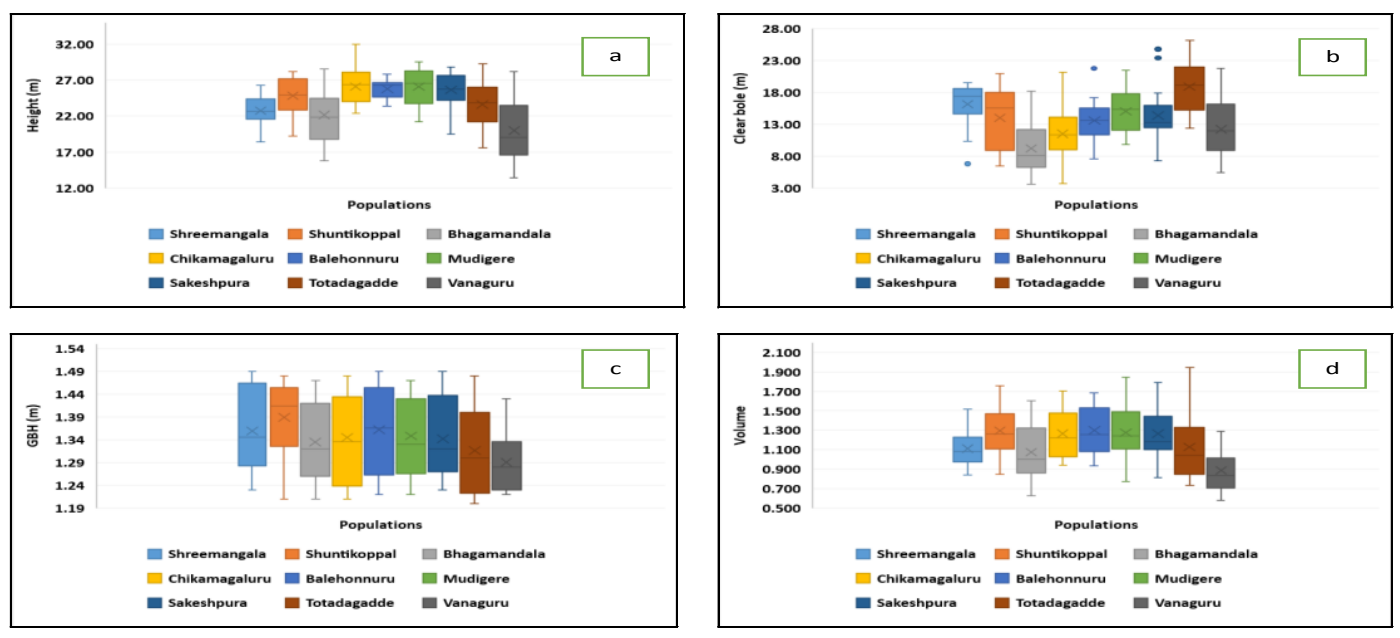
Fig.2 Dendrogram showing clusters of selected populations

Dendrogram using Average Linkage (Between Groups)

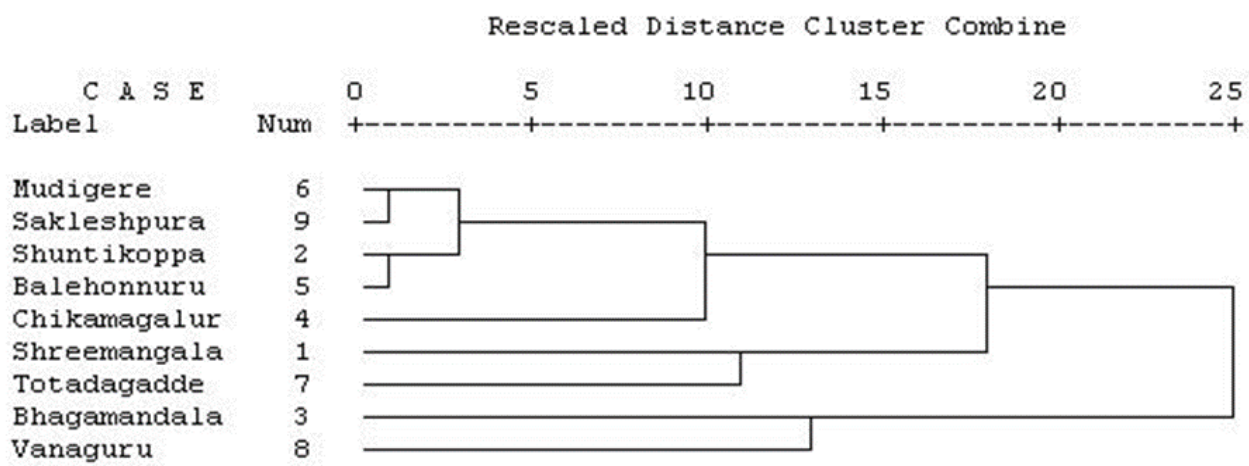

\section{Hierarchical Grouping}

Data collected for growth traits from nine populations were subjected to Hierarchical cluster analysis to categorize populations based on the degree of similarity. Based on Squared Euclidean distances, nine locations were grouped into three clusters. Cluster I had five populations (Mudigere, Sakleshpura, Shuntikoppa, Balehonnuru, Chikamagaluru), followed by cluster II with two populations (Bhagamandala, Vanaguru) and cluster III with two populations (Shreemangala, Totadagadde) (Table 3). The dendrogram (Fig. 2) was prepared using the Betweengroups linkage method to reveal a similar pattern of information.

All living organisms are unique in their scale of variability. In the absence of variability, no amount of selection pressure can significantly improve the character. In the present investigation, the variation across the population was significant. The variability in these growth parameters could be attributed to varying rainfall and other climatic factors along with the altitude and latitude. In a similar study by Prasd et al., (2010) in Dipterocarpus indicus natural populations from different parts of Western Ghats, attributed the variation in growth parameters to varying rainfall and latitude. Rowth (2016) noticed similar observations in natural habitats of Dalbergia latofolia and attributed the population variation to different altitudinal ranges. Similar observations have been made by Sharma et al., (2017) in Dalbergia sissoo, Pande et al., (2013) in Leucaena leucocephala in 24 populations from Andra Pradesh, Tamil Nadu and Orissa. Meena et al., (2014) attributed the variation in different growth and yield parameters of Melia azedarach to varying climatic condition.

The pattern of variability on growth traits was significant across the selected populations. Considering the important growth parameters, Balehonnuru, Shuntikoppa Chikamagaluru and Mudigere populations are found to be better compared to other populations. Future selections (candidate plus trees) could be made from these populations.

\section{Acknowledgement}

The authors sincerely thank the University of Agricultural and Horticultural Sciences, Shivamogga for this opportunity. We thank the College of Forestry, Ponnampet for providing technical support and suggestions during the research period. Also would like to thank Karnataka Forest Department for their support during field visits. 


\section{References}

Ghildyal, B. N., 1989. Introduction to Acrocarpus fraxinifolius - A fast growing species for Social Forestry in Himachal Pradesh. Indian Forester, 115(7):455-458.

Meena, H., Kumar, A., Sharma, R., Chauhan, S.K. and Bhargava, K.M., 2014. Genetic variation for growth and yield parameters in half-sib progenies of Melia azedarach (Linn.). Turkish Journal of Agriculture and Forestry, 38(4):531-539.

Mishra, G., Pandey, A. K., Arunachalam, M. K. and Rao, S., 2015. Global Scenario of Acrocarpus fraxinifolius Wight \& Arn. - A future tree of Agroforestry. International Letter of Natural Science., 3:25-29.

Nath, C. D., Boura, A., Franceschi, D. D. and Pélissier, R., 2012. Assessing the utility of direct and indirect methods for estimating tropical tree age in the Western Ghats, India. Trees, 26(1):1729.

Orwa, C. A., Mutua, K. R., Jamnadass, R. and Anthony, S., 2009. Agroforestry Database: a tree reference and selection guide, World Agroforestry Centre, Kenya, letter no. 14

Pande, P.K., Kumar, A., Ravichandran, S., Naithani, S., Kothiyal, V., Kishore, P.B.K., Raturi, A., Gautam, P., Dobhal,
S. and Sharma, S., 2013. Genetic analysis of growth and wood variations in Leucaena leucocephala (Lam.) de Wit. Journal of Forestry Research, 24(3):485-493.

Panse, V.G. and Sukhatme, P.V., 1978. Statistical methods for Agricultural workers. III Rev. Ed. ICAR, New Delhi.

Prasad, A. G. and Sagheer, N. A., 2010. Variations in Tree Growth of Dipterocarpus indicus among different Populations in Western Ghats India. International Journalof Environmental Science, Development \& Monitoring, 1(1):103-111.

Rowth, N., 2016. Variability studies in Dalbergia latifolia Roxb. M.Sc. Thesis, University of Agricultural and Horticultural Sciences, Shivamogga, India.

Sharma, K. B., Kumari, B., Johar, V. and Bisht, V., 2017. Plus tree Variation of Shisham (Dalbergia sissoo) in different Agro-Ecological Regions of Haryana. Environment \& Ecology, 35(4A): 2996 $-2998$.

Troup, R. S., 1921. Silviculture of Indian Trees (2), Asiatic Publishing House, Delhi, pp.338-341.

Zobel, B. and Talbert, J. J., 1984. Applied Forest Tree Improvement. John Wiley and Sons, New York, pp.75-116.

\section{How to cite this article:}

Ashwath, M. N., B. N. Satish, G. M. Devagiri, R. K. Hegde and Hareesh, T. S. 2020. Variation in Growth Traits of Acrocarpus fraxinifolius Wight \& Arn Populations in Southern Karnataka, India. Int.J.Curr.Microbiol.App.Sci. 9(08): 1838-1843.

doi: https://doi.org/10.20546/ijcmas.2020.908.210 